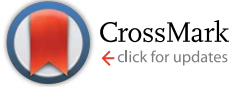

Cite this: RSC Adv., 2017, 7, 805

Received 5th October 2016 Accepted 21st October 2016

DOI: 10.1039/c6ra24751b

www.rsc.org/advances

\title{
Nine new compounds from the root bark of Lycium chinense and their $\alpha$-glucosidase inhibitory activity $\dagger$
}

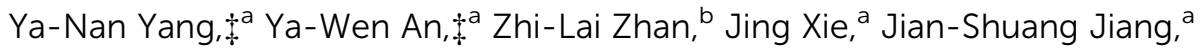 \\ Zi-Ming Feng, ${ }^{a}$ Fei $\mathrm{Ye}^{\mathrm{a}}$ and Pei-Cheng Zhang ${ }^{\star a}$
}

\begin{abstract}
Lycium chinense Mill. is a deciduous shrub in the Solanaceae family that is known for its fruits (Lycii fructus) and root bark (Lycii cortex). In our ongoing search for $\alpha$-glucosidase inhibitors from the root bark of $L$. chinense, lyciumflavane $\mathrm{A}$, one new flavane with an unusual benzofuran unit, one new amide possessing a naphthalene skeleton, one new sesquiterpene, three new lignan glucosides, and three new phenolic glucosides were isolated along with eight known compounds. Their structures were elucidated using NMR, HRESIMS, UV, ECD, and IR spectroscopic data. Their $\alpha$-glucosidase inhibitory activity was screened using acarbose as a positive control $\left(\mathrm{IC}_{50}=385 \mu \mathrm{M}\right)$. Compound 1 showed strong inhibitory activity against $\alpha$-glucosidase $\left(\mathrm{IC}_{50}=20.89 \mu \mathrm{M}\right)$.
\end{abstract}

\section{Introduction}

Lycium chinense Mill. is cultivated in the mainland of China and is an important source for health foods and traditional Chinese medicine. ${ }^{1-3}$ The root bark of $L$. chinense, named Digupi in China, is conventionally used in traditional Chinese medicine prescriptions to treat diabetes, coughs, hypertension, and fever. Modern pharmacological studies revealed that extracts from the root bark of $L$. chinense can lower serum glucose levels and improve insulin resistance., ${ }^{\mathbf{4} 5}$ Previously, phytochemical investigations of this plant have shown the presence of alkaloids, lignanamides, cyclopeptides, lignans, and sterols. ${ }^{6-12}$

With the aim of discovering new bioactive natural products with hypoglycemic effects from the root bark of $L$. chinense, an oral sucrose tolerance test (OSTT) was performed. The results demonstrated that the water-soluble portion of the root bark of L. chinense obtained from an $80 \%$ EtOH extract could significantly decrease the postprandial blood glucose levels in normal ICR mice at a dose of $200 \mathrm{mg} \mathrm{kg}^{-1}$ (Fig. S1, ESI $\dagger$ ), which is similar to the hypoglycemic effect of acarbose $\left(20 \mathrm{mg} \mathrm{kg}^{-1}\right)$. Through bioactivity-guided isolation, one new flavane with an unusual benzofuran unit, one new amide possessing a naphthalene skeleton, one new sesquiterpene, three new lignan

${ }^{a}$ State Key Laboratory of Bioactive Substance and Function of Natural Medicines, Institute of Materia Medica, Chinese Academy of Medical Sciences, Peking Union Medical College, Beijing 100050, People's Republic of China. E-mail: pczhang@imm.ac.cn

${ }^{b}$ State Key Laboratory Breeding Base of Dao-di Herbs, National Resource Center for Chinese Materia Medica, China Academy of Chinese Medical Sciences, Beijing, 100700, People's Republic of China

$\dagger$ Electronic supplementary information (ESI) available: 1D NMR, 2D NMR HRMS, IR, and ECD spectra. See DOI: 10.1039/c6ra24751b

\$ These authors contributed equally. glucosides, and three new phenolic glucosides were obtained from the root bark of $L$. chinense along with eight known compounds (Fig. 1). In this paper, we reported the isolation and structure elucidation of compounds 1-9 and evaluated these compounds as $\alpha$-glucosidase inhibitors.

\section{Results and discussion}

The molecular formula of $\mathbf{1}$ was determined to be $\mathrm{C}_{22} \mathrm{H}_{22} \mathrm{O}_{4}$ by the positive ion peak at $m / z 351.1586[\mathrm{M}+\mathrm{H}]^{+}$in the HRESIMS, which indicated 12 degrees of unsaturation. The ${ }^{1} \mathrm{H}$ NMR spectrum of 1 (Table 1 ) revealed an $\mathrm{ABX}$ system aromatic ring at $\delta_{\mathrm{H}} 6.88(1 \mathrm{H}, \mathrm{d}, J=8.0 \mathrm{~Hz}), 6.29(1 \mathrm{H}, \mathrm{dd}, J=2.0,8.0 \mathrm{~Hz})$, and 6.18 $(1 \mathrm{H}, \mathrm{d}, J=2.0 \mathrm{~Hz})$, a pentasubstituted aromatic ring at $\delta_{\mathrm{H}} 7.17$ $(1 \mathrm{H}, \mathrm{s})$, three olefinic protons at $\delta_{\mathrm{H}} 6.88(1 \mathrm{H}, \mathrm{d}, J=2.0 \mathrm{~Hz}), 7.91$ $(1 \mathrm{H}, \mathrm{d}, J=2.0 \mathrm{~Hz})$, and $5.07(1 \mathrm{H}, \mathrm{m})$, an oxymethylene proton at $\delta_{\mathrm{H}} 5.08(1 \mathrm{H}$, br d, $J=11.0 \mathrm{~Hz})$, three methylene protons at $\delta_{\mathrm{H}}$ $3.49(1 \mathrm{H}, \mathrm{m}), 3.42(1 \mathrm{H}, \mathrm{m}), 2.82(1 \mathrm{H}, \mathrm{m}), 2.66(1 \mathrm{H}, \mathrm{m}), 2.09(1 \mathrm{H}$, $\mathrm{m})$, and $1.88(1 \mathrm{H}, \mathrm{m})$, and two methyl groups at $\delta_{\mathrm{H}} 1.67(3 \mathrm{H}, \mathrm{s})$ and $1.61(3 \mathrm{H}, \mathrm{s})$. The ${ }^{13} \mathrm{C}$ NMR and HSQC spectra of 1 displayed 22 carbon resonances including an isopentene group, two olefinic carbons and a C6-C3-C6 unit, which could be attributed to a flavone skeleton.

From the HMBC spectrum, the correlations of $\mathrm{H}-2\left[\delta_{\mathrm{H}} 5.08\right.$ $(1 \mathrm{H}, \mathrm{d}, J=10.0 \mathrm{~Hz})]$ to $\mathrm{C}-1^{\prime}\left(\delta_{\mathrm{C}} 135.6\right)$ and $\mathrm{C}-6^{\prime}\left(\delta_{\mathrm{C}} 109.1\right)$ as well as the correlations of $\mathrm{H}-6^{\prime}\left[\delta_{\mathrm{H}} 7.17(1 \mathrm{H}, \mathrm{s})\right]$ to $\mathrm{C}-2\left(\delta_{\mathrm{C}} 74.6\right), \mathrm{C}-1^{\prime}\left(\delta_{\mathrm{C}}\right.$ 135.6), C-2 ${ }^{\prime}\left(\delta_{\mathrm{C}}\right.$ 122.3), $\mathrm{C}-4^{\prime}\left(\delta_{\mathrm{C}}\right.$ 143.5), and $\mathrm{C}-5^{\prime}\left(\delta_{\mathrm{C}} 126.2\right)$ confirmed the basic skeleton of the flavane. The correlations of $\mathrm{H}-5\left[\delta_{\mathrm{H}} 6.88(1 \mathrm{H}, \mathrm{d}, J=8.0 \mathrm{~Hz})\right]$ to $\mathrm{C}-9\left(\delta_{\mathrm{C}} 156.4\right)$ and C-7 $\left(\delta_{\mathrm{C}} 155.7\right)$ suggested the existence of $7-\mathrm{OH}$ at ring A of the flavane. Moreover, the isopentene group was connected to the $\mathrm{C}-2^{\prime}\left(\delta_{\mathrm{C}} 122.3\right)$ of ring $\mathrm{B}$ because the $\mathrm{H}-1^{\prime \prime}\left[\delta_{\mathrm{H}} 3.42(1 \mathrm{H}, \mathrm{m})\right]$ was correlated with $\mathrm{C}-1^{\prime}$ 


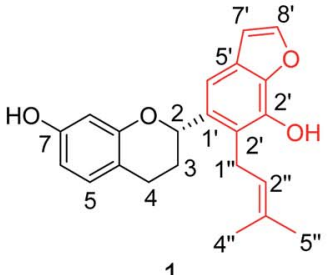
1

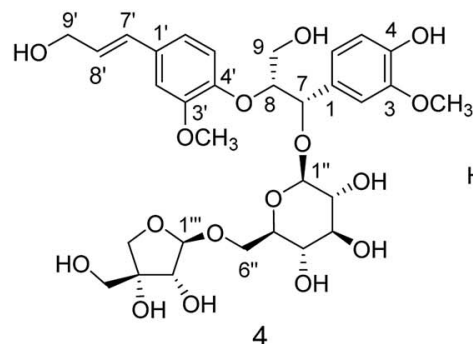
4

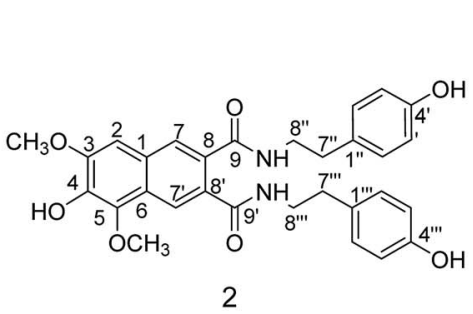

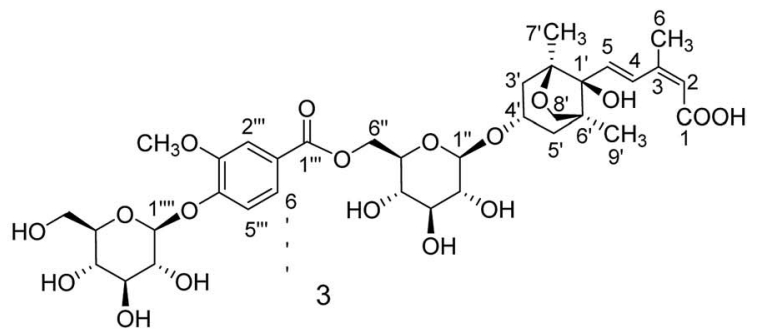

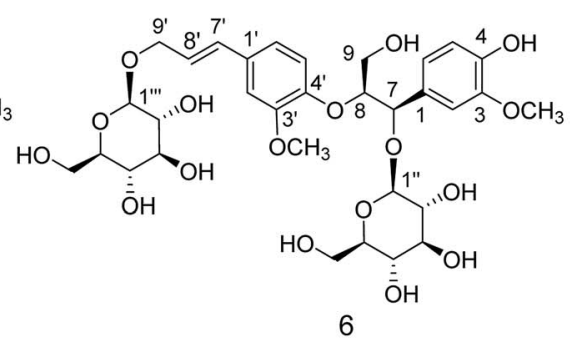<smiles>[3H]C(O[C@@H]1O[C@H](COC2OC[C@@H](O)[C@H](O)[C@H]2O)[C@@H](O)[C@H](O)[C@H]1O)c1ccc(OC)c(OC)c1</smiles>

7<smiles>CC(C)=CCc1cc([C@H]2CCc3ccc(O)cc3O2)c(CC=C(C)C)c(O)c1O</smiles>

10<smiles>Oc1ccc2c(c1)OCc1c-2oc2cc3c(cc12)OCO3</smiles>

14

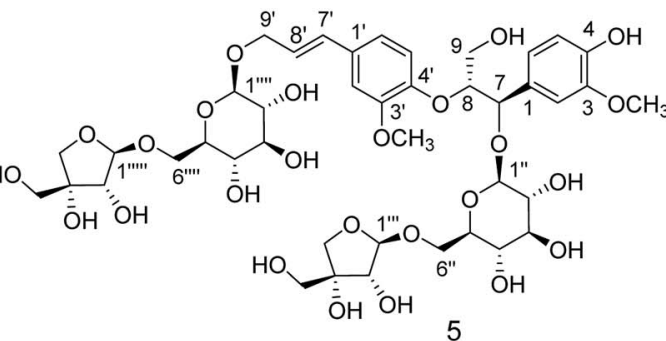<smiles>COc1cc([C]O[C]2OC(CO[C]3OC[C@@H](O)[C@H](O)[C@H]3O)[C@@H](O)[C@H](O)[C@H]2O)cc(OC)c1OC</smiles>

8<smiles>C=CCc1cc([C@H]2CCc3ccc(O)cc3O2)ccc1O</smiles>

15<smiles>COc1ccc([C@H]2CC(=O)c3c(O)cc(O)cc3O2)cc1</smiles>

12<smiles>OC[C@]1(O)CO[C](OCC2O[C](OCC=Cc3ccc(O)cc3)[C@H](O)[C@@H](O)[C@H]2O)[C@@H]1O</smiles>

9<smiles>C[C@@H]1O[C@H](Oc2c(-c3ccc(O)c(O)c3)oc3cc(O)cc(O)c3c2=O)[C@H](O)[C@@H](O)[C@H]1O</smiles>

Fig. 1 Chemical structures of 1-17.

$\left(\delta_{\mathrm{C}} 135.6\right), \mathrm{C}-2^{\prime}\left(\delta_{\mathrm{C}} 122.3\right)$, and $\mathrm{C}-3^{\prime}\left(\delta_{\mathrm{C}} 139.3\right)$. By considering the remaining two degrees of unsaturation and the molecular formula, the benzofuran unit was established, which was supported by the HMBC correlations (Fig. 2) from $\mathrm{H}-7^{\prime}\left[\delta_{\mathrm{H}} 6.88(1 \mathrm{H}\right.$, $\mathrm{d}, J=2.0 \mathrm{~Hz})]$ to $\mathrm{C}-4^{\prime}\left(\delta_{\mathrm{C}} 143.5\right), \mathrm{C}-5^{\prime}\left(\delta_{\mathrm{C}} 126.2\right)$, and C-8 ${ }^{\prime}\left(\delta_{\mathrm{C}} 145.3\right)$ and from $\mathrm{H}-8^{\prime}\left[\delta_{\mathrm{H}} 7.91(1 \mathrm{H}, \mathrm{d}, J=2.0 \mathrm{~Hz})\right]$ to $\mathrm{C}-4^{\prime}\left(\delta_{\mathrm{C}} 143.5\right)$ and $\mathrm{C}-$ $5^{\prime}\left(\delta_{\mathrm{C}} 126.2\right)$. In addition, the $2 S$ configuration was confirmed by the negative Cotton effect at $280 \mathrm{~nm}$ in the ECD spectrum. ${ }^{15}$ So, compound 1 was established as shown, and was accorded the trivial name lyciumflavane A.

Compound 2 was obtained as a yellow amorphous powder. The molecular formula, $\mathrm{C}_{30} \mathrm{H}_{30} \mathrm{~N}_{2} \mathrm{O}_{7}$, was established by the protonated molecular ion peak at $m / z 531.2131[\mathrm{M}+\mathrm{H}]^{+}$(calcd for $\mathrm{C}_{30} \mathrm{H}_{31} \mathrm{~N}_{2} \mathrm{O}_{7}, 531.2131$ ) in the HRESIMS, which corresponded to 17 degrees of unsaturation. In the ${ }^{1} \mathrm{H}$ NMR spectrum of 2 (Table
1), the presence of two $p$-tyramine moieties was deduced from two $\mathrm{AA}^{\prime} \mathrm{BB}^{\prime}$ spin system aromatic rings $\left[\delta_{\mathrm{H}} 7.06(2 \mathrm{H}, \mathrm{d}, J=8.5 \mathrm{~Hz})\right.$, $6.69(2 \mathrm{H}, \mathrm{d}, J=8.5 \mathrm{~Hz}), 7.08(2 \mathrm{H}, \mathrm{d}, J=8.5 \mathrm{~Hz})$ and $6.71(2 \mathrm{H}, \mathrm{d}, J$ $=8.5 \mathrm{~Hz})]$, two pairs of methylene proton signals $\left[\delta_{\mathrm{H}} 2.72(4 \mathrm{H}, \mathrm{m})\right.$ and $3.36(4 \mathrm{H}, \mathrm{m})]$, and two $\mathrm{NH}$ signals $\left[\delta_{\mathrm{H}} 8.40(1 \mathrm{H}, \mathrm{t}, J=5.5 \mathrm{~Hz})\right.$ and $8.34(1 \mathrm{H}, \mathrm{t}, J=5.5 \mathrm{~Hz})]$. Simultaneously, another three aromatic protons at $\delta_{\mathrm{H}} 7.16(1 \mathrm{H}, \mathrm{s}), 7.75(1 \mathrm{H}, \mathrm{s})$, and $7.83(1 \mathrm{H}, \mathrm{s})$, and two methoxy groups at $\delta_{\mathrm{H}} 3.93(3 \mathrm{H}, \mathrm{s})$ and $3.87(3 \mathrm{H}, \mathrm{s})$ were also observed. The ${ }^{13} \mathrm{C}$ NMR spectrum (Table 2) of 2 revealed 30 carbon signals, 20 of which were assigned to two $p$-tyramine moieties, two carbonyl groups and two methoxy groups, and the remaining 10 carbons were assigned to a naphthalene unit combined with the degrees of unsaturation. The HMBC correlations (Fig. 2) of $\mathrm{H}-8^{\prime \prime} / \mathrm{C}-9, \mathrm{H}-8^{\prime \prime \prime} / \mathrm{C}-9^{\prime}, \mathrm{H}-7 / \mathrm{C}-9$, and $\mathrm{H}-\mathrm{7}^{\prime} / \mathrm{C}-9^{\prime}$ suggested that 2 was an amide possessing a naphthalene skeleton. 
Table $1{ }^{1} \mathrm{H}$ NMR data of $1-6$ in DMSO- $d_{6}(500 \mathrm{MHz}, \delta$ in ppm, $\mathrm{J}$ in $\mathrm{Hz}$ )

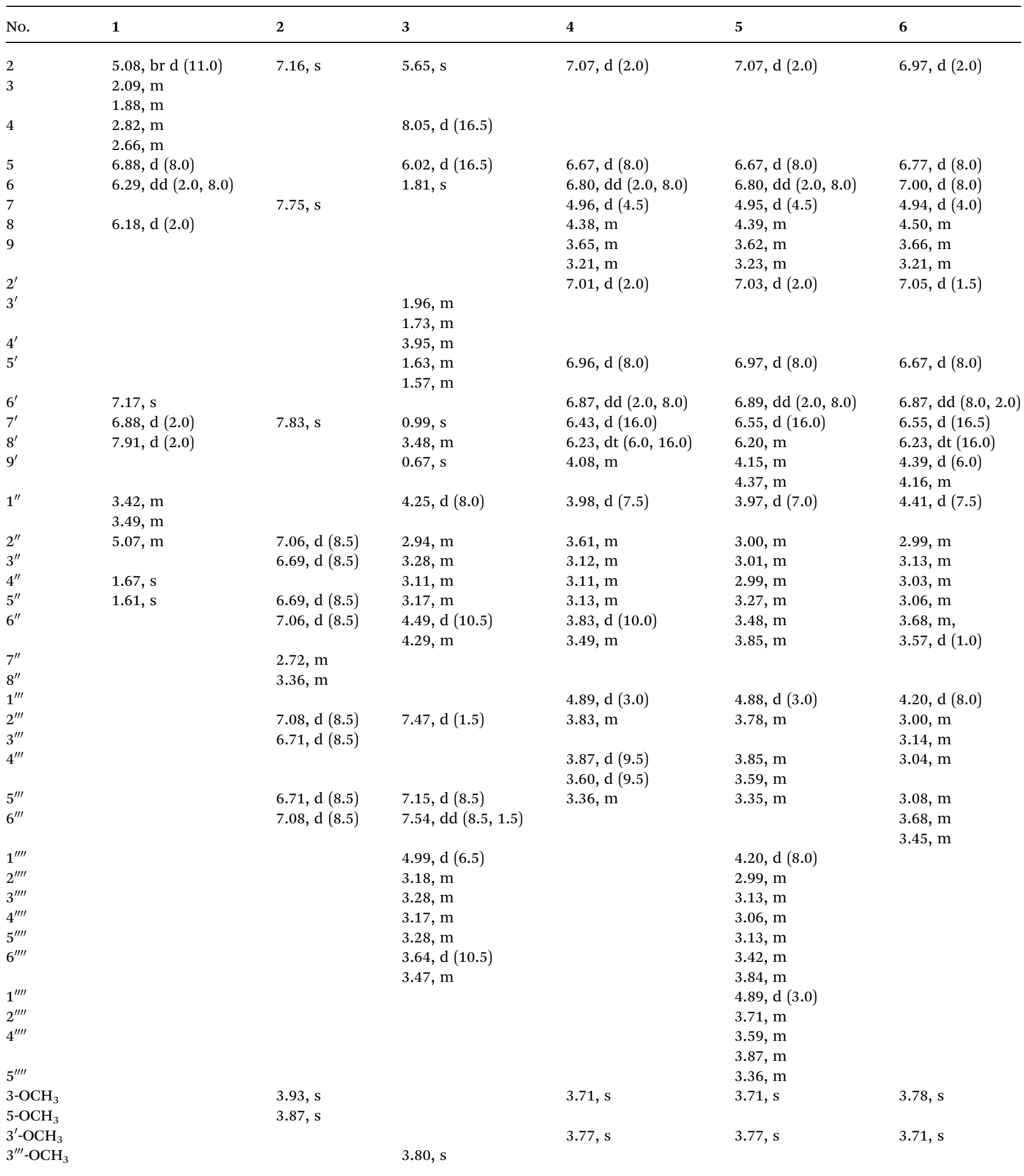

The linkage points of the two methoxy groups were confirmed to be at $\mathrm{C}-3$ and $\mathrm{C}-5$ based on the correlations between the methoxy protons $\left(\delta_{\mathrm{H}} 3.93\right)$ with $\mathrm{C}-3$ and the methoxy protons $\left(\delta_{\mathrm{H}} 3.87\right)$ with $\mathrm{C}-5$ in the HMBC spectrum. Thus, compound 2 was elucidated as shown and was named lyciumamide A.
Compound 3 was isolated as a yellow powder. The molecular formula was established to be $\mathrm{C}_{35} \mathrm{H}_{48} \mathrm{O}_{18}$ by the HRESIMS ion peak at $m / z[\mathrm{M}+\mathrm{Na}]^{+} 779.2723\left(\mathrm{C}_{35} \mathrm{H}_{48} \mathrm{O}_{18} \mathrm{Na}\right.$, calcd for 779.2733). The UV, IR, and NMR spectra of 3 were similar to dihydrophaseic acid $4^{\prime}$-O-( $6^{\prime \prime}$-O-galloyl)- $\beta$-D-glucopyranoside; ${ }^{16}$ the differences 


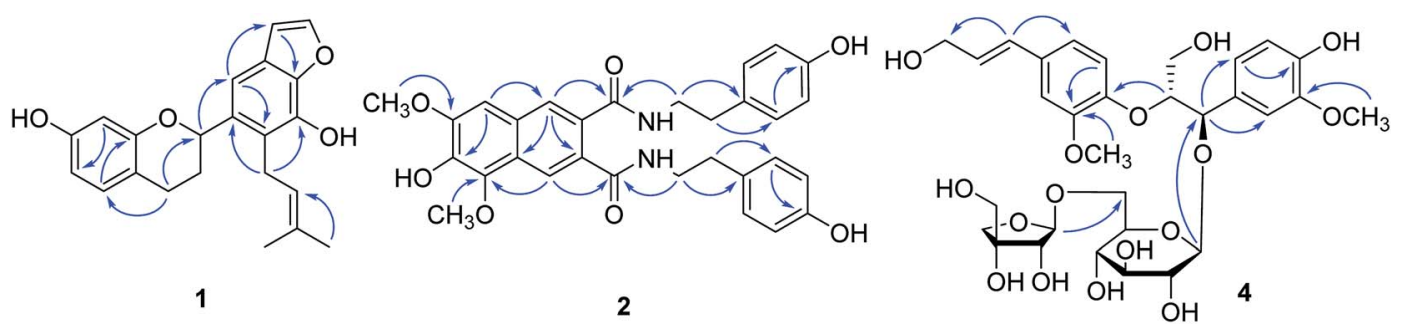

Fig. 2 Key HMBC correlations of 1, 2, and 4

between the compounds were that $\mathbf{3}$ contained an additional glucose unit and a vanilloyl group in place of the galloyl in dihydrophaseic acid $4^{\prime}-O-\left(6^{\prime \prime}\right.$-O-galloyl)- $\beta$-D-glucopyranoside. In the HMBC spectrum of 3 , the correlations from $\mathrm{H}-1^{\prime \prime \prime \prime}\left(\delta_{\mathrm{H}} 4.99\right)$ to $\mathrm{C}-4^{\prime \prime \prime}\left(\delta_{\mathrm{C}} 150.7\right)$ established the linkage position of the additional glucose. Compound 3 was assigned as lyciumoside A.

Compound 4 was obtained as a white powder. The molecular formula, $\mathrm{C}_{31} \mathrm{H}_{42} \mathrm{O}_{16}$, was established by a sodiated molecular ion peak observed at $\mathrm{m} / \mathrm{z} 693.2377[\mathrm{M}+\mathrm{Na}]^{+}$(calcd for $\left.\mathrm{C}_{31} \mathrm{H}_{42} \mathrm{O}_{16} \mathrm{Na}, 693.2365\right)$ in the HRESIMS. The ${ }^{1} \mathrm{H}$ NMR spectrum of 4 (Table 1) exhibited two ABX spin system aromatic protons at $\delta_{\mathrm{H}} 7.07(1 \mathrm{H}, \mathrm{d}, J=2.0 \mathrm{~Hz}), 6.67(1 \mathrm{H}, \mathrm{d}, J=8.0 \mathrm{~Hz})$, $6.80(1 \mathrm{H}, \mathrm{dd}, J=2.0,8.0 \mathrm{~Hz}), 7.01(1 \mathrm{H}, \mathrm{d}, J=2.0 \mathrm{~Hz}), 6.96(1 \mathrm{H}, \mathrm{d}$, $J=8.0 \mathrm{~Hz})$, and $6.87(1 \mathrm{H}, \mathrm{dd}, J=2.0,8.0 \mathrm{~Hz})$, and two olefinic protons at $\delta_{\mathrm{H}} 6.43(1 \mathrm{H}, \mathrm{d}, J=16.0 \mathrm{~Hz})$ and $6.23(1 \mathrm{H}, \mathrm{dt}, J=6.0$, $16.0 \mathrm{~Hz})$. Two oxygenated methine protons at $\delta_{\mathrm{H}} 4.96(1 \mathrm{H}, \mathrm{d}, J=$ $4.5 \mathrm{~Hz})$ and $4.38(1 \mathrm{H}, \mathrm{m})$, four oxygenated methylene protons at $\delta_{\mathrm{H}} 3.65(1 \mathrm{H}, \mathrm{m}), 3.21(1 \mathrm{H}, \mathrm{m})$, and $4.08(2 \mathrm{H}, \mathrm{m})$, two methoxy groups at $\delta_{\mathrm{H}} 3.71(3 \mathrm{H}, \mathrm{s})$ and $3.77(3 \mathrm{H}, \mathrm{s})$, and two anomeric protons at $\delta_{\mathrm{H}} 3.98(1 \mathrm{H}, \mathrm{d}, J=7.5 \mathrm{~Hz})$ and $4.89(1 \mathrm{H}, \mathrm{d}, J=3.0 \mathrm{~Hz})$ were observed in the upfield region. The ${ }^{13} \mathrm{C}$ NMR and HSQC spectra displayed a total of 31 carbon signals. Apart from one glucopyranose moiety, one apiofuranose moiety, and two methoxy groups, the remaining 18 carbon signals were assigned to two C6-C3 units. The key HMBC correlations (Fig. 2) of H-7 at $\delta_{\mathrm{H}} 4.96$ with C-1, 2, 6, 8, and 9, of $\mathrm{H}-7^{\prime}$ at $\delta_{\mathrm{H}} 6.43$ with C-1 ${ }^{\prime}, 2^{\prime}, 6^{\prime}$, $8^{\prime}$, and $9^{\prime}$, and of $\mathrm{H}-8$ at $\delta_{\mathrm{H}} 4.38$ with C- $4^{\prime}$ at $\delta_{\mathrm{C}} 147.7$ suggested that 4 was an $8-0-4^{\prime}$ system neolignan. ${ }^{17}$ The methoxy groups were confirmed to be at $\mathrm{C}-3$ and $\mathrm{C}-3^{\prime}$ based on the HMBC correlations of the methoxy groups at $\delta_{\mathrm{H}} 3.71$ and 3.77 with C-3 and $\mathrm{C}-3^{\prime}$, respectively. The HMBC correlation of $\mathrm{H}-1^{\prime \prime}\left(\delta_{\mathrm{H}} 3.98\right)$ with C-7 $\left(\delta_{\mathrm{C}} 76.1\right)$ revealed that the glucopyranose unit was attached to $\mathrm{C}-7$, while the correlation of $\mathrm{H}-1^{\prime \prime \prime}\left(\delta_{\mathrm{H}} 4.89\right)$ with C- 6 " $\left(\delta_{\mathrm{C}} 67.3\right)$ suggested that the apiofuranose unit was attached to C$6^{\prime \prime}$. On the basis of the above analysis, the planner structure of 4 was similar to that of ligusinenoside $\mathrm{D},{ }^{18}$ except for the position of sugar moiety. Acid hydrolysis of $\mathbf{4}$ yielded $\mathbf{4 a}$, D-glucopyranose and D-apiofuranose, which were identified by GC analysis of their trimethylsilyl L-cysteine derivatives. Furthermore, the $\beta$ linkage of D-glucopyranose and D-apiofuranose was determined by their anomeric protons at $\delta_{\mathrm{H}} 3.98(1 \mathrm{H}, \mathrm{d}, J=7.5 \mathrm{~Hz})$ and $\delta_{\mathrm{H}}$ $4.89(1 \mathrm{H}, \mathrm{d}, J=3.0 \mathrm{~Hz})$. The ${ }^{1} \mathrm{H}$ NMR experiment of $4 \mathbf{a}$ was performed in $\mathrm{CDCl}_{3}$. A small coupling constant $\left(J_{7,8}=4.5 \mathrm{~Hz}\right)$ between $\mathrm{H}-7$ and $\mathrm{H}-8$ indicated the erythro configuration of C-7 and C-8 unambiguously. ${ }^{19}$ This result combined with the negative Cotton effect at $231 \mathrm{~nm}$ in the $\mathrm{CD}$ spectrum of 4 established the $7 S, 8 R$ configurations for $4 .^{19}$ From the above data, the structure of $\mathbf{4}$ was assigned as shown (Fig. 1), and this compound was named lyciumlignan A.

The molecular formula of 5 was determined to be $\mathrm{C}_{42} \mathrm{H}_{60} \mathrm{O}_{25}$ on the basis of the sodiated molecular ion peak observed at $\mathrm{m} / \mathrm{z}$ $987.3316[\mathrm{M}+\mathrm{Na}]^{+}$in the HRESIMS. A comparison of the UV and NMR data of $\mathbf{5}$ with those of $\mathbf{4}$ revealed that the aglycone of $\mathbf{5}$ was also an 8-O-4' system neolignan. Its ${ }^{1} \mathrm{H}$ NMR spectrum exhibited four anomeric protons at $\delta_{\mathrm{H}} 3.97(1 \mathrm{H}, \mathrm{d}, J=7.0 \mathrm{~Hz}), 4.88(1 \mathrm{H}, \mathrm{d}, J$ $=3.0 \mathrm{~Hz}), 4.20(1 \mathrm{H}, \mathrm{d}, J=8.0 \mathrm{~Hz})$, and $4.89(1 \mathrm{H}, \mathrm{d}, J=3.0 \mathrm{~Hz})$, which indicated the existence of two glucopyranose units and two apiofuranose units with the $\beta$-linkage. The key HMBC correlations of $\mathrm{H}-1^{\prime \prime}\left(\delta_{\mathrm{H}} 3.97\right)$ to $\mathrm{C}-7\left(\delta_{\mathrm{C}} 76.3\right), \mathrm{H}-1^{\prime \prime \prime \prime}\left(\delta_{\mathrm{H}} 4.20\right)$ to $\mathrm{C}-9^{\prime}\left(\delta_{\mathrm{C}}\right.$ $68.6), \mathrm{H}-1^{\prime \prime \prime}\left(\delta_{\mathrm{H}} 4.88\right)$ to $\mathrm{C}-6^{\prime \prime}\left(\delta_{\mathrm{C}} 67.4\right)$, and $\mathrm{H}-1^{\prime \prime \prime \prime}\left(\delta_{\mathrm{H}} 4.89\right)$ to C-6 $6^{\prime \prime \prime \prime}$ $\left(\delta_{\mathrm{C}} 67.7\right)$ clearly presented the planner structure for compound 5 as 4,9-dihydroxy-3,3'-dimethoxy-7-en-8, $4^{\prime}$-oxyneolignan-7-O- $\beta$-Dapiofuranosyl-( $(1 \rightarrow 6)-\beta$-D-glucopyranosyl-9'-O- $\beta$-D-apiofuranosyl$(1 \rightarrow 6)-\beta$-D-glucopyranoside. Acid hydrolysis of 5 resulted in $5 a$, Dglucopyranose, and D-apiofuranose. The D-configurations of these two sugars were determined by GC analysis. In the ${ }^{1} \mathrm{H}$ NMR spectrum of $5 \mathbf{a}\left(\mathrm{CDCl}_{3}\right)$, the characteristic coupling constant of $\mathrm{H}^{-}$ $7\left(J_{7,8}=7.5 \mathrm{~Hz}\right)$ allowed for the determination of the thero configuration of $\mathrm{C}-7$ and $\mathrm{C}-8 .{ }^{18}$ By considering the negative Cotton effects at $231 \mathrm{~nm}(\Delta \varepsilon-1.82)$ in 5 that were exhibited in the CD spectrum, the $7 R, 8 R$ configurations were confirmed. ${ }^{18}$ Thus, 5 was characterized as shown and named lyciumlignan $B$.

Detailed analysis of the 1D NMR spectra (Tables 1 and 2) suggested that the structure of $\mathbf{6}$ was similar to that of $\mathbf{5}$. The difference between these two compounds was the absence of two apiofuranose units at C-6" and C-6"' in 6. Using the same method that was described for 5 , the absolute configurations of $\mathrm{C}-7$ and $\mathrm{C}-8$ in 6 were established as $7 R, 8 S$. Therefore, the structure of 6 (lyciumlignan $\mathrm{C}$ ) was determined to be $(7 R, 8 S)$ 4,9-dihydroxy-3,3'-dimethoxy-7-en-8, $4^{\prime}$-oxyneolignan-7-O- $\beta$-Dglucopyranosyl-9'-O- $\beta$-D-glucopyranoside.

Compound 7 exhibited a molecular formula of $\mathrm{C}_{20} \mathrm{H}_{30} \mathrm{O}_{12}$ according to the positive HRESIMS ion observed at $\mathrm{m} / \mathrm{z} 485.1633$ $[\mathrm{M}+\mathrm{Na}]^{+}$. The ${ }^{1} \mathrm{H}$ NMR spectrum (Table 3 ) of 7 revealed a set of ABX system aromatic protons at $\delta_{\mathrm{H}} 7.00(1 \mathrm{H}, \mathrm{d}, J=2.0 \mathrm{~Hz}), 6.88$ (1H, overlap), and $6.88(1 \mathrm{H}$, overlap), two oxymethylene protons at $\delta_{\mathrm{H}} 4.70(1 \mathrm{H}, \mathrm{d}, J=12.0 \mathrm{~Hz})$ and $4.50(1 \mathrm{H}, \mathrm{d}, J=12.0 \mathrm{~Hz})$, and two methoxyl protons at $\delta_{\mathrm{H}} 3.73(3 \mathrm{H}, \mathrm{s})$ and $3.74(3 \mathrm{H}, \mathrm{s})$. Moreover, two anomeric protons at $\delta_{\mathrm{H}} 4.16(1 \mathrm{H}, \mathrm{d}, J=8.0 \mathrm{~Hz})$ and $4.24(1 \mathrm{H}, \mathrm{d}, J=7.5 \mathrm{~Hz})$ observed in the upfield region 
Table $2{ }^{13} \mathrm{C}$ NMR data of $1-6$ in DMSO- $d_{6}(125 \mathrm{MHz}, \delta$ in ppm)

\begin{tabular}{|c|c|c|c|c|c|c|}
\hline No. & 1 & 2 & 3 & 4 & 5 & 6 \\
\hline 1 & & 123.2 & 177.5 & 128.6 & 128.4 & 129.7 \\
\hline 2 & 74.6 & 102.4 & 126.8 & 111.6 & 111.7 & 111.8 \\
\hline 3 & 29.6 & 151.0 & 141.4 & 147.1 & 147.2 & 149.6 \\
\hline 4 & 24.6 & 139.8 & 131.0 & 145.8 & 145.8 & 145.7 \\
\hline 5 & 129.9 & 140.5 & 129.9 & 114.7 & 114.7 & 115.1 \\
\hline 6 & 108.0 & 126.7 & 20.5 & 120.1 & 120.1 & 119.7 \\
\hline 7 & 155.7 & 126.3 & & 76.1 & 76.3 & 77.6 \\
\hline 8 & 102.8 & 126.8 & & 82.9 & 83.0 & 81.8 \\
\hline 9 & 156.4 & 168.4 & & 60.5 & 60.6 & 59.8 \\
\hline 10 & 112.1 & & & & & \\
\hline $1^{\prime}$ & 135.6 & & 81.0 & 130.2 & 129.7 & 129.7 \\
\hline $2^{\prime}$ & 122.3 & & 85.3 & 110.0 & 110.1 & 109.7 \\
\hline $3^{\prime}$ & 139.3 & & 42.0 & 149.6 & 149.6 & 147.6 \\
\hline $4^{\prime}$ & 143.5 & & 72.8 & 147.7 & 148.1 & 147.6 \\
\hline $5^{\prime}$ & 126.2 & & 41.8 & 115.7 & 115.7 & 114.6 \\
\hline $6^{\prime}$ & 109.1 & & 47.5 & 119.1 & 119.4 & 119.4 \\
\hline $7^{\prime}$ & 107.7 & 120.0 & 19.5 & 128.5 & 131.7 & 131.4 \\
\hline $8^{\prime}$ & 145.3 & 131.7 & 75.0 & 128.4 & 123.8 & 124.1 \\
\hline $9^{\prime}$ & & 168.6 & 16.0 & 61.6 & 68.6 & 68.7 \\
\hline $1^{\prime \prime}$ & 23.9 & 129.6 & 102.2 & 100.3 & 100.2 & 102.1 \\
\hline $2^{\prime \prime}$ & 123.8 & 129.5 & 73.3 & 73.3 & 73.4 & 74.2 \\
\hline $3^{\prime \prime}$ & 129.8 & 115.0 & 77.1 & 76.6 & 76.6 & 77.1 \\
\hline $4^{\prime \prime}$ & 25.4 & 155.6 & 70.6 & 70.0 & 70.0 & 69.9 \\
\hline $5^{\prime \prime}$ & 17.7 & 115.0 & 73.6 & 75.3 & 75.3 & 76.8 \\
\hline $6^{\prime \prime}$ & & 129.5 & 64.3 & 67.3 & 67.4 & 61.0 \\
\hline $7^{\prime \prime}$ & & 34.1 & & & & \\
\hline $8^{\prime \prime}$ & & 41.1 & & & & \\
\hline $1^{\prime \prime \prime}$ & & 129.6 & 123.0 & 109.3 & 109.2 & 102.2 \\
\hline $2^{\prime \prime \prime}$ & & 129.7 & 112.7 & 75.9 & 75.9 & 73.5 \\
\hline $3^{\prime \prime \prime}$ & & 115.1 & 148.6 & 78.8 & 78.8 & 76.9 \\
\hline $4^{\prime \prime \prime}$ & & 155.6 & 150.7 & 73.4 & 73.3 & 70.1 \\
\hline $5^{\prime \prime \prime}$ & & 115.1 & 114.5 & 63.3 & 63.1 & 76.5 \\
\hline $6^{\prime \prime \prime}$ & & 129.7 & 122.8 & & & 61.1 \\
\hline $7^{\prime \prime \prime}$ & & 34.3 & 165.1 & & & \\
\hline $8^{\prime \prime \prime}$ & & 41.1 & & & & \\
\hline $1^{\prime \prime \prime \prime \prime}$ & & & 99.6 & & 101.8 & \\
\hline $2^{\prime \prime \prime \prime}$ & & & 73.1 & & 73.4 & \\
\hline $3^{\prime \prime \prime \prime}$ & & & 76.8 & & 76.6 & \\
\hline $4^{\prime \prime \prime \prime \prime}$ & & & 69.4 & & 70.3 & \\
\hline $5^{\prime \prime \prime \prime}$ & & & 76.5 & & 75.6 & \\
\hline $6^{\prime \prime \prime \prime \prime}$ & & & 60.4 & & 67.7 & \\
\hline $1^{\prime \prime \prime \prime \prime}$ & & & & & 109.3 & \\
\hline $2^{\prime \prime \prime \prime}$ & & & & & 75.9 & \\
\hline $3^{\prime \prime \prime \prime \prime}$ & & & & & 78.8 & \\
\hline $4^{\prime \prime \prime \prime \prime}$ & & & & & 73.2 & \\
\hline $5^{\prime \prime \prime \prime \prime}$ & & & & & 63.3 & \\
\hline $3-\mathrm{OCH}_{3}$ & & 55.8 & & 55.4 & 55.7 & 55.5 \\
\hline $5-\mathrm{OCH}_{3}$ & & 60.4 & & & & \\
\hline $3^{\prime}-\mathrm{OCH}_{3}$ & & & & 55.7 & 55.4 & 55.4 \\
\hline $3^{\prime \prime \prime}-\mathrm{OCH}_{3}$ & & & 55.7 & & & \\
\hline
\end{tabular}

confirmed the presence of two sugar moieties with a $\beta$-linkage. The ${ }^{13} \mathrm{C}$ NMR spectrum showed 20 carbon signals that could be assigned to a glucopyranose unit, a xylopyranose unit, two methoxy groups, and a benzylalcohol moiety. The HMBC correlation peaks of the two methoxy groups at $\delta_{\mathrm{H}} 3.73$ and 3.74 with C-3 and C-4 confirmed the linkage positions of these methoxy groups. The sequence of two sugar units was determined to be $\beta$-xylopyranosyl- $(1 \rightarrow 6)-O-\beta$-glucopyranosyl based on correlations from $\mathrm{H}-\mathbf{1}^{\prime \prime}$ to $\mathrm{C}-6^{\prime}$ in the HMBC spectrum. The unusual downfield shift of the $\mathrm{H}-7\left(\delta_{\mathrm{H}} 4.70,4.50\right)$ and $\mathrm{C}-7\left(\delta_{\mathrm{C}}\right.$
69.3) was an important indicator that the sugar moiety occurred at C-7. This was supported by the HMBC correlation that was observed from $\mathrm{H}-1^{\prime}\left(\delta_{\mathrm{H}} 4.16\right)$ to C-7. Finally, the structure of 7 was elucidated as $3^{\prime}, 4^{\prime}$-dimethoxy-benzylalcohol-1- $O$ - $\beta$-D-xylopyranosyl-( $1 \rightarrow 6)-O$ - $\beta$-D-glucopyranoside.

A comparison of the IR, UV, and NMR data (Table 3) of $\mathbf{8}$ with those of 7 revealed that the difference between these two compounds was the presence of an additional methoxy group at C-5 in 8. This result was supported by the HMBC correlation from $\mathrm{OCH}_{3}-3,5$ to C-3, 5, and the singlet proton signal at $\delta_{\mathrm{H}} 6.71$ $(2 \mathrm{H}, \mathrm{s})$ in the ${ }^{1} \mathrm{H}$ NMR spectrum. So, compound 8 was elucidated as $3^{\prime}, 4^{\prime}, 5^{\prime}$-trimethoxy-benzylalcohol-1-O- $\beta$-D-xylopyranosyl- $(1 \rightarrow 6)-O$ - $\beta$-D-glucopyranoside.

Compound 9 was obtained as a white powder. The molecular formula, $\mathrm{C}_{20} \mathrm{H}_{28} \mathrm{O}_{11}$, was established by the positive molecular ion peak at $m / z 467.1531[\mathrm{M}+\mathrm{Na}]^{+}$(calcd for $\mathrm{C}_{20} \mathrm{H}_{28} \mathrm{O}_{11} \mathrm{Na}$, 467.1524) in the HRESIMS. The ${ }^{1} \mathrm{H}$ NMR spectrum of 9 revealed an $\mathrm{AA}^{\prime} \mathrm{BB}^{\prime}$ spin system $\left[\delta_{\mathrm{H}} 7.25(2 \mathrm{H}, \mathrm{d}, J=9.0 \mathrm{~Hz})\right.$ and $6.71(2 \mathrm{H}$, $\mathrm{d}, J=9.0 \mathrm{~Hz})]$, two trans olefince proton signals $\left[\delta_{\mathrm{H}} 6.53(1 \mathrm{H}, \mathrm{d}, J\right.$ $=16.0 \mathrm{~Hz})$ and $6.10(1 \mathrm{H}, \mathrm{d}, 16.0 \mathrm{~Hz})]$, two oxymethylene proton signals $\left[\delta_{\mathrm{H}} 4.44(1 \mathrm{H}, \mathrm{m})\right.$ and $\left.4.13(1 \mathrm{H}, \mathrm{m})\right]$, and two anomeric proton signals $\left[\delta_{\mathrm{H}} 4.19(1 \mathrm{H}, \mathrm{d}, J=7.5 \mathrm{~Hz})\right.$ and $4.88(1 \mathrm{H}, \mathrm{d}, J=3.0$ $\mathrm{Hz}$ )]. In the ${ }^{13} \mathrm{C}$ NMR spectrum (Table 3), aside from the 11 carbon signals of a glucopyranose unit and an apiofuranose unit, the remaining nine carbon signals could be attributed to a $p$-coumaryl alcohol moiety. Subsequently, the two sugar units were determined to be $\beta$-apiofuranosyl- $(1 \rightarrow 6)-O$ - $\beta$-glucopyranosyl by the characteristic correlation of $\mathrm{H}-1^{\prime \prime}$ with $\mathrm{C}-6^{\prime}$ in the HMBC spectrum. In combination with the HMBC correlation of $\mathrm{H}-1^{\prime}$ with C-9, compound 9 was defined as $4^{\prime}$-hydroxystyrone-1$O$ - $\beta$-D-apiofuranosyl-( $1 \rightarrow 6)-O$ - $\beta$-D-glucopyranoside.

Based on the spectroscopic data and a comparison with those found in the literature, the eight known compounds (Fig. 1) were established as kazinol A (10), ${ }^{20,21} 7,4^{\prime}$-dihydroxyisopentene flavane (11), ${ }^{22}$ acacetin (12), ${ }^{23}$ quercitrin (13), ${ }^{24}$ maackianin (14) ${ }^{25}$ maackiain (15) ${ }^{26}(7 R, 8 S)-4,9,9^{\prime}$-trihydroxy3,3'-dimethoxy-7'-en-8,4'-oxyneolignan-7-O- $\beta$-D-glucopyranoside (16), ${ }^{27}$ and 2-hydroxy-4-methoxybenzaldehyde-2-O- $\beta$-D-glucopyraneosyl-1-6-O- $\beta$-D-xylopyranoside (17) ${ }^{28}$

\section{Experimental}

\section{General experimental procedures}

The optical rotations, UV spectra, and ECD spectra were measured on JASCO P-2000 polarimeter, JASCO V650 spectrometer, and JASCO J-815 spectrometer (JASCO, Easton, MD, USA), respectively. Infrared (IR) spectra were recorded on a Nicolet 5700 spectrometer (Thermo Scientific, Waltham, MA, USA). 1D and 2D NMR spectra were recorded with a Bruker 500 MHz spectrometer (Bruker-Biospin, Billerica, MA, USA). Highresolution electrospray ionization mass spectrometry (HRESIMS) was performed on an Agilent 6520 HPLC-Q-TOF (Agilent Technologies, Waldbronn, Germany). Flash chromatography was performed using a Combiflash RF200 apparatus (Teledyne Isco Corp., Lincoln, NE, USA). Preparative and semi-preparative HPLC (pHPLC and semi-pHPLC) were performed using a Shimadzu preparative chromatography system (Shimadzu Corp., 
Table $3{ }^{1} \mathrm{H}$ and ${ }^{13} \mathrm{C}$ NMR data of 7-9 in DMSO- $d_{6}\left(500 \mathrm{MHz}\right.$ for ${ }^{1} \mathrm{H}$ NMR, $125 \mathrm{MHz}$ for ${ }^{13} \mathrm{C} \mathrm{NMR}$ )

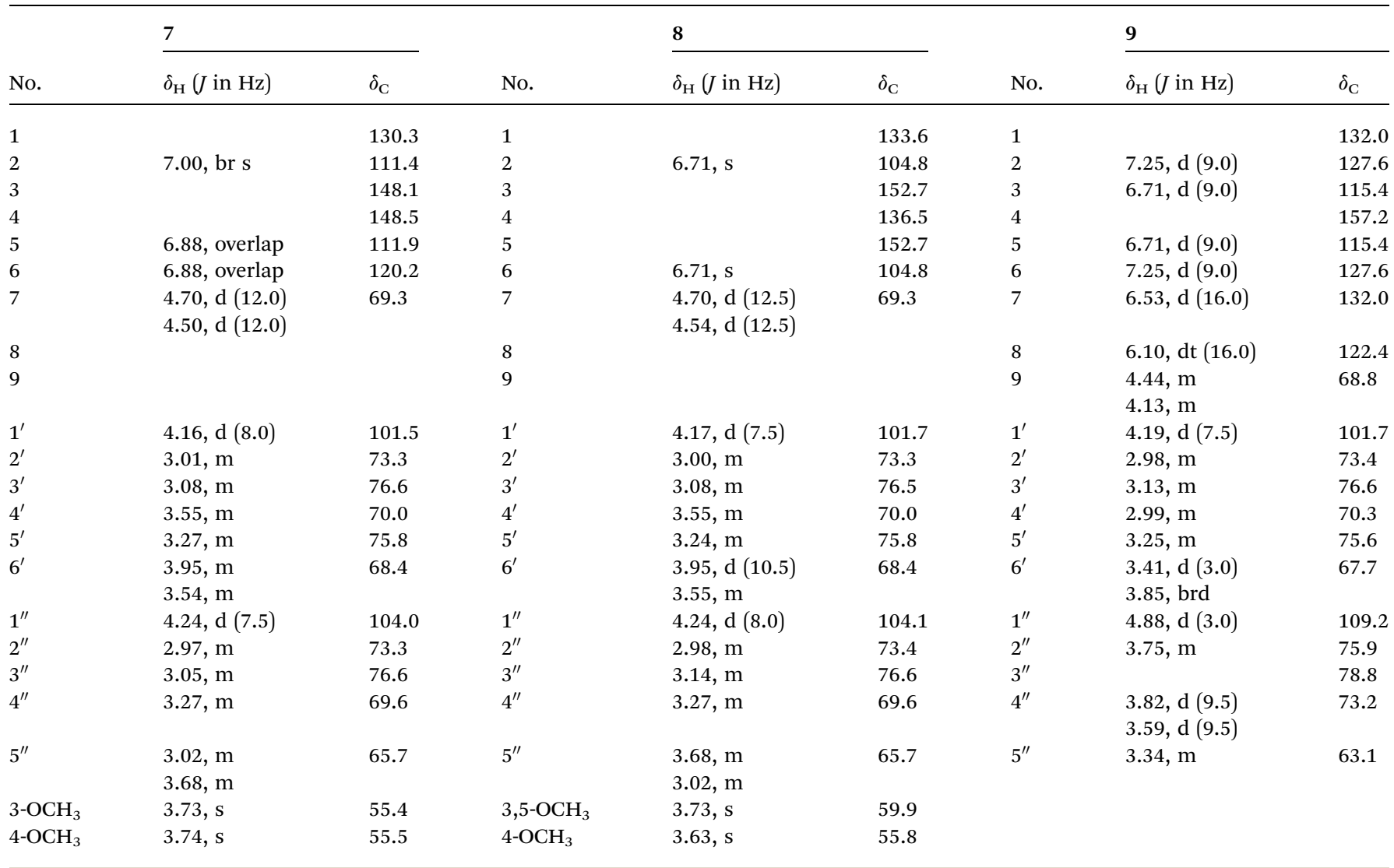

Tokyo, Japan) with YMC-Pack ODS-A columns $(250 \mathrm{~mm} \times 20 \mathrm{~mm}$, $5 \mu \mathrm{m} ; 250 \mathrm{~mm} \times 10 \mathrm{~mm}, 5 \mu \mathrm{m}$; YMC Corp., Kyoto, Japan). GC analysis was performed using on an Agilent 7890A instrument. HPLC-DAD analysis was conducted on an Agilent 1200 instrument with a $\mathrm{YMC} \mathrm{C}_{18}$ column $(250 \mathrm{~mm} \times 4.6 \mathrm{~mm}, 5 \mu \mathrm{m})$.

\section{Plant material}

The root bark of the $L$. chinense was collected from Ningan Town, Zhongning County, Ningxia Hui autonomous region, People's Republic of China, in March 2012. A voucher specimen (ID-S-2592) was deposited in the Herbarium of the Institute of Materia Medica, Chinese Academy of Medical Science, Beijing.

\section{Extraction and isolation}

The powdered plant material $(100 \mathrm{~kg})$ was extracted three times with $80 \%$ EtOH (600 L) under reflux. The solvent was evaporated and the crude residue $(8.0 \mathrm{~kg})$ was partitioned with EtOAc $(3 \times 45$ L). The EtOAc and $\mathrm{H}_{2} \mathrm{O}$ solvent were removed under reduced pressure, which yielded Fr. 1 and Fr. 2, respectively. Fr. 2 (1.375 kg) was chromatographed with a macroporous resin column (HP-20, $200 \times 15 \mathrm{~cm}$ ) and eluted successively with $\mathrm{H}_{2} \mathrm{O}, 15 \%, 30 \%, 50 \%$, $70 \%$, and $95 \% \mathrm{EtOH}$. The $30 \% \mathrm{EtOH}$ fraction was concentrated and was further chromatographed over a macroporous resin (SP$700,200 \times 15 \mathrm{~cm}$ ) and eluted successively with $15 \%, 20 \%, 25 \%$, $30 \%, 45 \%, 50 \%$, and $95 \% \mathrm{EtOH}$, which yielded fractions A-G.
Fr. C (72 g) was subjected to Combiflash RF200 apparatus with a $\mathrm{C}_{18}$ column $(55 \times 8 \mathrm{~cm}, 50 \mu \mathrm{m})$ and eluted with $\mathrm{MeOH}-$ $\mathrm{H}_{2} \mathrm{O}$ (from $5: 95$ to $100: 0$ ) to provide Fr. C1-Fr. C25. Fr. C5 (3 g) was chromatographed over Sephadex LH-20 and eluted with gradient mixtures of $\mathrm{MeOH}-\mathrm{H}_{2} \mathrm{O}$ (from $10: 90$ to $95: 5$ ) to yield Fr. C5-1-C5-15. Fr. C5-4 was purified with pHPLC $\left(\mathrm{MeOH}-\mathrm{H}_{2} \mathrm{O}, 45: 55\right)$ to yield 5 (20 mg). Fraction C5-11 was chromatographed over Sephadex $\mathrm{LH}-20$ using $\mathrm{MeOH}-\mathrm{H}_{2} \mathrm{O}$ (from $0: 100$ to $60: 40$ ) as the gradient mobile phase system and was further purified with pHPLC to yield 3 (26 mg), 6 (16 $\mathrm{mg}$ ), and 17 (35 mg). Fraction C7 ( $5 \mathrm{~g}$ ) was subjected to the Rp$\mathrm{C}_{18}(50 \mu \mathrm{m})$ and eluted with $\mathrm{MeOH}-\mathrm{H}_{2} \mathrm{O}$ (from $10: 90$ to $100: 0)$ to yield Fr. C7-1-C7-8. 4 (17 mg) was obtained from Fr. C7-3 by pHPLC $\left(\mathrm{MeOH}-\mathrm{H}_{2} \mathrm{O}, 30: 70\right)$. Fr. C7-5 was purified using pHPLC with $\mathrm{MeOH}-\mathrm{H}_{2} \mathrm{O}(40: 60)$ as the mobile phase to yield $16(12 \mathrm{mg})$ and $9(24 \mathrm{mg})$. Fr. C10 (1.8 g) was subjected to the Rp- $\mathrm{C}_{18}(50 \mu \mathrm{m})$ and eluted with $\mathrm{MeOH}-\mathrm{H}_{2} \mathrm{O}(15: 85)$ to give six fractions (Fr. C10-1-C10-6). Purification of Fr. C10-2 (1.8 g) with $\mathrm{MeOH}-\mathrm{H}_{2} \mathrm{O}(20: 80)$ on pHPLC yielded 7 (32 mg) and 8 (19 mg).

Fraction G (4 g) was chromatographed over Sephadex LH-20 with a gradient of $\mathrm{H}_{2} \mathrm{O}-\mathrm{MeOH}$ (from $60: 40$ to $0: 100$ ) to yield Fr. G1-G11. Fr. G2 was purified by pHPLC $\left(\mathrm{MeOH}-\mathrm{H}_{2} \mathrm{O}, 50: 50\right)$ to yield $13(25 \mathrm{mg})$ and $2(20 \mathrm{mg}) .11$ (33 mg) and $12(27 \mathrm{mg})$ were obtained from Fr. G5 by pHPLC $\left(\mathrm{MeOH}-\mathrm{H}_{2} \mathrm{O}, 65: 35\right)$ as the mobile phase. Fr. G7 was purified by pHPLC $\left(\mathrm{MeOH}-\mathrm{H}_{2} \mathrm{O}\right.$, $70: 30)$ to yield $14(29 \mathrm{mg})$ and $15(22 \mathrm{mg})$. Fr. G9 and Fr. G10 
were purified by pHPLC with $\mathrm{MeOH}-\mathrm{H}_{2} \mathrm{O}(70: 30)$ to yield 1 (28 $\mathrm{mg}$ ) and 10 (15 mg), respectively.

\section{Structure characterization}

Lyciumflavane A, 1. $[\alpha]_{\mathrm{D}}^{20}-8.7(c 0.10, \mathrm{MeOH}) ; \mathrm{CD}(\mathrm{MeOH})$ $\lambda_{\max }(\Delta \varepsilon): 219(-1.03)$ and $276(-0.08) \mathrm{nm} ; \mathrm{UV}(\mathrm{MeOH}) \lambda_{\max }$ (log $\varepsilon$ ): 207 (4.24), 255 (2.95), and 285 (2.53) nm; IR (KBr) $\nu_{\max }$ : 3364, 2926, 1598, 1509, 1460, 1378, 1261, 1155, 1114, 1041, 956, and $801 \mathrm{~cm}^{-1}$; and (+)-HRESIMS: $m / z 351.1586[\mathrm{M}+\mathrm{H}]^{+}$(calcd for $\left.\mathrm{C}_{22} \mathrm{H}_{23} \mathrm{O}_{4}, 351.1596\right)$. For the NMR data, see Tables 1 and 2.

Lyciumamide A, 2. UV (MeOH) $\lambda_{\max }(\log \varepsilon): 202$ (4.15), 237 (3.79), and 258 (4.05) nm; IR (KBr) $\nu_{\text {max }}: 3325,2940,1635,1515$, 1452 1241, 1122, 1087, 910, 827, and $560 \mathrm{~cm}^{-1}$; and (+)-HRESIMS: $m / z 531.2131[\mathrm{M}+\mathrm{H}]^{+}$(calcd for $\mathrm{C}_{30} \mathrm{H}_{31} \mathrm{~N}_{2} \mathrm{O}_{7}$, 531.2131). For the NMR data, see Tables 1 and 2.

Lyciumoside A, 3. $[\alpha]_{\mathrm{D}}^{20}-5.31$ (c 0.10, $\left.\mathrm{MeOH}\right)$; $\mathrm{CD}(\mathrm{MeOH})$ $\lambda_{\max }(\Delta \varepsilon): 217(-2.67), 251(-0.77)$, and $276(-0.31) \mathrm{nm} ; \mathrm{UV}$ $(\mathrm{MeOH}) \lambda_{\max }(\log \varepsilon): 207$ (4.25), 215 (4.28), 256 (4.26), and 297 (3.49) nR (KBr) $\nu_{\text {max }}: 3379,2930,1712,1601,1417,1274,1074$, 1026, 883, and $764 \mathrm{~cm}^{-1}$; and (+)-HRESIMS: $m / z$ 779.2723 [M + $\mathrm{Na}]^{+}$(calcd for $\mathrm{C}_{35} \mathrm{H}_{48} \mathrm{O}_{18} \mathrm{Na}, 779.2738$ ). For the NMR data, see Tables 1 and 2.

Lyciumlignan A, 4. $[\alpha]_{\mathrm{D}}^{20}-45.5(c 0.10 \mathrm{MeOH})$; $\mathrm{CD}(\mathrm{MeOH})$ $\lambda_{\max }(\Delta \varepsilon): 231$ (-1.10), $255(+0.84)$, and $284(+1.99) ; \mathrm{UV}(\mathrm{MeOH})$ $\lambda_{\max }(\log \varepsilon): 206$ (4.57), 268 (3.89), and 301 (3.49); IR (KBr) $\nu_{\max }$ : 3371, 2936, 2881, 1698, 1604, 1513, 1268, 1034, 823, and 621 $\mathrm{cm}^{-1}$; and (+)-HRESIMS: $\mathrm{m} / z$ 693.2377 $[\mathrm{M}+\mathrm{Na}]^{+}$(calcd for $\left.\mathrm{C}_{31} \mathrm{H}_{42} \mathrm{O}_{16} \mathrm{Na}, 693.2371\right)$. For the NMR data, see Tables 1 and 2.

Lyciumlignan B, 5. $[\alpha]_{\mathrm{D}}^{20}-66.7(c 0.10 \mathrm{MeOH})$; $\mathrm{CD}(\mathrm{MeOH})$ $\lambda_{\max }(\Delta \varepsilon): 231(-1.82), 253(+0.79)$, and $285(+2.02) ; \mathrm{UV}(\mathrm{MeOH})$ $\lambda_{\max }(\log \varepsilon): 205$ (4.54), 268 (3.95), and 304 (3.32); IR (KBr) $\nu_{\max }$ : 3368, 2974, 2931, 2885, 1513, 1419, 1268, 1049, 825, and 617 $\mathrm{cm}^{-1}$; and (+)-HRESIMS: $\mathrm{m} / z$ 987.3316 $[\mathrm{M}+\mathrm{Na}]^{+}$(calcd for $\mathrm{C}_{42} \mathrm{H}_{60} \mathrm{O}_{25} \mathrm{Na}$, 987.3321). For the NMR data, see Tables 1 and 2.

Lyciumlignan C, 6. $[\alpha]_{\mathrm{D}}^{20}+16.93(c 0.07 \mathrm{MeOH})$; $\mathrm{CD}(\mathrm{MeOH})$ $\lambda_{\max }(\Delta \varepsilon): 230(+0.80) ; \mathrm{UV}(\mathrm{MeOH}) \lambda_{\max }(\log \varepsilon): 205$ (4.35), 271 (3.71), and 301 (3.61); IR (KBr) $\nu_{\text {max }}: 3384,2930,1565,1513$, 1420, 1267, 1078, 1031, 670, and $618 \mathrm{~cm}^{-1}$; and (+)-HRESIMS: $m / z 723.2485[\mathrm{M}+\mathrm{Na}]^{+}$(calcd for $\mathrm{C}_{32} \mathrm{H}_{44} \mathrm{O}_{17} \mathrm{Na}, 723.2476$ ). For the NMR data, see Tables 1 and 2.

$3^{\prime}, 4^{\prime}$-Dimethoxy-benzylalcohol-1-O- $\beta$-D-xylopyranosyl- $(1 \rightarrow 6)$ $\boldsymbol{O}$ - $\boldsymbol{\beta}$-D-glucopyranoside, 7. $[\alpha]_{\mathrm{D}}^{20}-35.9\left(\begin{array}{cccc}c & 0.10 & \mathrm{MeOH}\end{array}\right) ; \quad \mathrm{UV}$ $(\mathrm{MeOH}) \lambda_{\max }(\log \varepsilon): 203$ (4.09), 221 (3.61), and 279 (2.93) nm; IR (KBr) $\nu_{\text {max }}: 3612,3429,2932,2835,1514,1449,1368,1258,1050$, and $668 \mathrm{~cm}^{-1}$; and (+)-HRESIMS: $m / z 485.1633[\mathrm{M}+\mathrm{Na}]^{+}$(calcd for $\left.\mathrm{C}_{20} \mathrm{H}_{30} \mathrm{O}_{12} \mathrm{Na}, 485.1635\right)$. For the NMR data, see Table 3.

$3^{\prime}, 4^{\prime}, 5^{\prime}$-Trimethoxy-benzylalcohol-1-O- $\beta$-D-xylopyranosyl-( $\left.1 \rightarrow 6\right)$ $\boldsymbol{O}-\boldsymbol{\beta}$-D-glucopyranoside, 8. $[\alpha]_{\mathrm{D}}^{20}-15.9$ (c $\left.0.10 \mathrm{MeOH}\right)$; UV (MeOH) $\lambda_{\max }(\log \varepsilon): 207$ (4.19), 233 (3.55), and 269 (3.17) nm; IR (KBr) $\nu_{\text {max }}$ : 3368, 2935, 1594, 1461, 1423, 1334, 1239, 1126, 1044, and 832 $\mathrm{cm}^{-1}$; and (+)-HRESIMS: $\mathrm{m} / z$ 515.1741 $[\mathrm{M}+\mathrm{Na}]^{+}$(calcd for $\mathrm{C}_{21} \mathrm{H}_{32} \mathrm{O}_{13} \mathrm{Na}$, 515.1741). For the NMR data, see Table 3.

4'-Hydroxystyrone-1- $O$ - $\beta$-D-apiofuranosyl- $(1 \rightarrow 6)$ - $O$ - $\beta$-D-glucopyranoside, 9. $[\alpha]_{\mathrm{D}}^{20}-10.4(c 0.10 \mathrm{MeOH}) ; \mathrm{UV} \lambda_{\max }(\mathrm{MeOH}) \mathrm{nm}$ : 206 (4.25), 263 (4.05), and 297 (3.46); (+)-HRESIMS: $m / z 467.1531$ $[\mathrm{M}+\mathrm{Na}]^{+}$(calcd for $\left.\mathrm{C}_{20} \mathrm{H}_{28} \mathrm{O}_{11} \mathrm{Na}, 467.1529\right)$; and IR (KBr) $\nu_{\max }$ :
$3360,2928,1609,1514,1446,1269,1050,853,767$, and 621 $\mathrm{cm}^{-1}$. For the NMR data, see Table 3 .

\section{Determination of the absolute configuration of sugar}

Compound 4 (8 mg) was dissolved in $0.5 \mathrm{M} \mathrm{HCl}(8 \mathrm{~mL})$ and refluxed for $4 \mathrm{~h}$. The reaction solution was then extracted with EtOAc $(3 \times 10 \mathrm{~mL})$. The EtOAc layer was concentrated to create a residue that was further purified using pHPLC with $\mathrm{MeOH}-\mathrm{H}_{2} \mathrm{O}$ (45:55) to yield $4 \mathrm{a}(3.5 \mathrm{mg})$. The aqueous layer was evaporated under a vacuum to create a monosaccharide residue. The residue was mixed with L-cysteine methyl ester hydrochloride ( $2 \mathrm{mg})$, and was dissolved in fresh anhydrous pyridine $(2.0 \mathrm{~mL})$. The reaction mixture was maintained at $60{ }^{\circ} \mathrm{C}$ for $2 \mathrm{~h}$. Then, the dried $\mathrm{N}$-trimethylsilylimidazole $(0.2 \mathrm{~mL})$ was added to the mixture. The solution was incubated at $60^{\circ} \mathrm{C}$ for $2 \mathrm{~h}$ and partitioned between $n$ hexane and $\mathrm{H}_{2} \mathrm{O}$. The $n$-hexane layer was subjected to GC analysis under the following conditions: capillary column, HP-5 (30 m $\times$ $0.32 \mathrm{~mm}$, with a $0.25 \mu \mathrm{m}$ film, Dikma); detector temperature, $300{ }^{\circ} \mathrm{C}$; injection temperature, $300{ }^{\circ} \mathrm{C}$; initial temperature, $200{ }^{\circ} \mathrm{C}$ that was raised to $280{ }^{\circ} \mathrm{C}$ at a rate of $10{ }^{\circ} \mathrm{C} \mathrm{min}{ }^{-1}$; the final temperature was maintained for $30 \mathrm{~min}$; detection, FID; and carrier gas, $\mathrm{N}_{2}$ gas. D-glucose and D-apiose were confirmed by comparing the retention time of their derivatives to the standard sugar derivatized in a similar manner, which exhibited retention times of 20.5 and $14.5 \mathrm{~min}$, respectively. The hydrolysis procedures for 5-9 were similar to that of $\mathbf{4}$. The D-xylose was confirmed by the retention time (14.9 $\mathrm{min}$ ) of its derivative.

\section{Inhibitory activity of $\alpha$-glucosidase}

The inhibitory activity of compounds 1-17 on $\alpha$-glucosidase was determined by the same method as described in the literature. ${ }^{13,14}$

\section{Conclusions}

In our ongoing effort to discover new bioactive natural products with hypoglycemic effects from the root bark of L. chinense, 17 compounds were isolated, including one new flavane with an unusual benzofuran unit, one new amide possessing a naphthalene skeleton, one new sesquiterpene, three new lignan glucosides, three new phenolic glucosides, and eight known compounds. A literature survey revealed that this is the first report of a flavane with an unusual benzofuran unit that showed strong inhibitory activity against $\alpha$-glucosidase $\left(\mathrm{IC}_{50}=20.89\right.$ $\mu \mathrm{M})$.

\section{Acknowledgements}

The research described in this publication was supported by the National Natural Science Foundation of China (No. 81303207) and the Beijing Natural Science Foundation (No. 7144227).

\section{References}

1 T. Wu, H. Y. Lv, F. Z. Wang and Y. Wang, J. Agric. Food Chem., 2016, 64, 2280-2288. 
2 N. C. Lin, J. C. Lin, S. H. Chen, C. T. Ho and A. I. Yeh, J. Agric. Food Chem., 2011, 59, 10088-10096.

3 K. Gao, D. W. Ma, Y. Cheng, X. R. Tian, Y. Y. Lu, X. Y. Du, H. F. Tang and J. Z. Chen, J. Agric. Food Chem., 2015, 63, 1067-1075.

4 Z. Ye, Q. Huang, H. X. Ni and D. Wang, Phytother. Res., 2008, 22, 1665-1670.

5 L. W. Xie, A. G. Atanasov, D. A. Guo, C. Malainer, J. X. Zhang, M. Zehl, S. H. Guan, E. H. Heiss, E. Urban, V. M. Dirsch and B. Kopp, J. Ethnopharmacol., 2014, 152, 470-477.

6 J. X. Zhang, S. H. Guan, R. H. Feng, Y. Wang, Z. Y. Wu, Y. B. Zhang, X. H. Chen, K. S. Bi and D. A. Guo, J. Nat. Prod., 2013, 76, 51-58.

7 S. Yahara, C. Shigeyama, T. Nohara, H. Okuda, K. Wakamatsu and T. Yasuhara, Tetrahedron Lett., 1989, 30, 6041-6042.

8 S. Yahara, C. Shigeyama, T. Ura, K. Wakamatsu, T. Yasuhara and T. Nohara, Chem. Pharm. Bull., 1993, 41, 703-709.

9 D. G. Lee, H. J. Jung and E. R. Woo, Arch. Pharmacal Res., 2005, 28, 1031-1036.

10 N. Mamoru and K. Mochida, J. Nat. Prod., 1985, 48, 342-343.

11 N. Afza, I. H. Qureshi and Y. Ahmad, J. Chem. Soc. Pak., 1987, 9, 627-628.

12 Y. W. An, Z. L. Zhan, J. Xie, Y. N. Yang, J. S. Jiang, Z. M. Feng, F. Ye and P. C. Zhang, J. Nat. Prod., 2016, 79, 1024-1034.

13 T. Li, X. D. Zhang, Y. W. Song and J. W. Liu, Chin. J. Clin. Pharmacol. Ther., 2005, 10, 1128-1134.

14 Y. N. Yang, F. S. Li, F. Liu, Z. M. Feng, J. S. Jiang and P. C. Zhang, RSC Adv., 2016, 6, 60741-60748.

$15 \mathrm{H}$. Achenbach, M. Stöcker and M. A. Constenla, Phytochemistry, 1988, 27, 1835-1841.
16 Y. Zhou, H. B. Chen, B. Wang, H. Liang, Y. Y. Zhao and Q. Y. Zhang, Planta Med., 2011, 77, 1944-1946.

17 X. Y. Huang, Z. M. Feng, Y. N. Yang, J. S. Jiang and P. C. Zhang, J. Asian Nat. Prod. Res., 2015, 17, 504-511.

18 J. P. Ma, C. H. Tan, D. Y. Zhu and L. Jin, Chin. Chem. Lett., 2011, 22, 1454-1456.

19 M. L. Gan, Y. L. Zhang, S. Lin, M. T. Liu, W. X. Song, J. C. Zi, Y. C. Yang, X. N. Fan, J. G. Shi, J. F. Hu, J. D. Sun and N. H. Chen, J. Nat. Prod., 2008, 71, 647-654.

20 J. Ikut, Y. Hano and T. Nomura, Heterocycles, 1985, 23, 28352842.

21 H. W. Ryu, B. W. Lee, M. J. Curtis-Long, S. Jung, Y. B. Ryu, W. S. Lee and K. H. Park, J. Agric. Food Chem., 2010, 58, 202208.

22 D. Lee, K. P. L. Bhat, H. H. S. Fong, N. R. Farnsworth, J. M. Pezzuto and A. D. Kinghorn, J. Nat. Prod., 2001, 64, 1286-1293.

23 J. M. J. Vasconcelos, A. M. S. Silva and J. A. S. Cavaleiro, Phytochemistry, 1998, 49, 1421-1424.

24 W. Peng, T. Han, Q. C. Liu and L. P. Qin, Chem. Nat. Compd., 2012, 48, 491-492.

25 R. B. Williams, M. O'Neil-Johnson, A. J. Williams, P. Wheeler, R. Pol and A. Moser, Org. Biomol. Chem., 2015, 13, 9957-9962.

26 P. M. Dewick and D. Ward, Phytochemistry, 1978, 17, 17511754.

27 J. P. Ma, C. H. Tan and D. Y. Zhu, J. Asian Nat. Prod. Res., 2008, 10, 565-569.

28 J. D. Msonthi, Bull. Chem. Soc. Ethiop., 1991, 5, 107-110. 